\title{
Perubahan Kesadaran Berzakat, atas Pengaruh Video Iklan Layanan Masyarakat dan Dampaknya pada Masyarakat Jateng dan DIY
}

\author{
Anton Bawono, Rifqi Aulia Erlangga \\ IAIN Salatiga, Indonesia \\ alfathbawono@gmail.com,_07rifqi@gmail.com
}

\begin{abstract}
This study aims to find out how much influence public service video ads have on zakat awareness. A total of 200 Muslim respondents from Central Java and Yogyakarta. The research method used is linear regression, which is processed with the help of SPSS 16.00 statistics. In addition to the study, a response was also made to the video on public service advertisements and a description of the awareness of the people of Central Java and Yogyakarta. From the findings, it was found that 19.2\% of zakat awareness increased after watching a public service advertisement video. Positive findings are expected to be the light of the people of Central Java and Yogyakarta to immediately pay zakat. The amil zakat institution is also expected to be helped in terms of increasing the zakat conscious movement through mass media facilities.
\end{abstract}

Keywords: Central Java and Yogyakarta Citizens, Zakat, Public Service Advertisement video

\begin{abstract}
Abstrak
Penelitian ini bertujuan untuk mengetahui seberapa besar pengarub video iklan layanan masyarakat terhadap kesadaran berzakat. Sebanyak 200 responden muslim Jawa Tengah dan Yogyakarta. Metode penelitian yang digunakan adalah regresi linier, dimana diolah dengan bantuan statistik SPSS 16.00. Sebagai tambahan dari studi, dijabarkan pula tanggapan atas video iklan layanan masyarakat dan uraian kesadaran masyarakat Jawa Tengah dan Yogyakarta. Dari hasil temuan, didapatkan babwa 19,2\% kesadaran berzakat meningkat setelah menyaksikan video iklan layanan masyarakat. Hasil temuan yang positif diharapkan menjadi pemantik masyarakat Jawa Tengah dan Yogyakarta untuk segera berzakat. Lembaga amil zakat juga diharapkan menjadi terbantu dari segi meningkatkan gerakan sadar zakat melalui sarana media massa.
\end{abstract}

Kata Kunci: Masyarakat Jawa Tengah dan Yogyakarta, Zakat, Video iklan Layanan Masyarakat

Permalink/DOI: http://dx.doi.org/10.18326/infsl3.v13i1.149-176 


\section{Latar Belakang Masalah}

Berkaitan dengan zakat, memang bukan merupakan hal baru, ini merupakan bagian dari rukun Islam yang wajib bagi muslim yang mampu. Sebagaimana diriwayatkan oleh Bukhori Muslim melalui haditsnya, bahwa Islam dibangun atas syahadat, sholat, zakat, haji serta puasa Ramadhan. Di atas hadis, tuntutan membayar zakat juga difirmankan oleh Allah diantaranya di dalam Al Qur'an surat Al Baqarah ayat 43, dan ayat 103 dari surat At Taubah.

Saat ini di tanah air, setidaknya di Jawa Tengah, "gerakan sadar zakat" sedang cukup gencar dikampanyekan. Pada akhir Maret 2018 di TVRI Jawa Tengah, secara live kementrian agama provinsi mengangkat tema tersebut di acara "Cahaya Qalbu." Dan ternyata di awal bulan, melalui berita yang disajikan republika.co.id, Kabupaten banyumas juga sedang menggeliatkan "gerakan sadar zakat." Sehingga merujuk pada dua media tadi, agaknya gerakan ini memang cukup serius sedang diperjuangkan di lapangan.

Merujuk pada "gerakan sadar zakat" di Banyumas, menurut ketua BAZNAS disana, Zakat yang terkumpul itu akan didistribusikan kepada masyarakat dalam berbagai bentuk, diantaranya seperti pemberian paket sembako, biaya pengobatan, santunan bagi penyandang cacat, modal usaha bagi pedagang kecil, bedah rumah, bantuan untuk korban bencana, dan bantuan biaya pendidikan.(republika.co.id,http://khazanah.republika. co.id/berita/dunia-islam/wakaf/18/03/05/p53ra6313-banyumasgeliatkan-gerakan-sadar-zakat.)

Untuk mengukur kesadaran zakat tentu diperlukan banyak langkah ilmiah agar dihasilkan kadar yang paling mendekati kenyataan dilapangan. Dan perlu diketahui bahwa mengukur kesadaran masyarakat melalui riset ini didasarkan atas teori kesadaran dari Ajzen dan Fishbein (1967) yang disesuaikan dengan riset-riset terkait zakat.

Cara untuk mengajak dan menyadarkan zakat masayarakat untuk aktif membayarkan zakat penting ini perlu difikirkan salah satunya dengan jenis media iklan. Dalam hal ini, iklan merupakan salah satu bentuk pesan persuasif yang memiliki peran penting 
dalam menyampaikan maksud dan tujuan suatu perusahaan. Maka dari itu, hal terpenting dalam strategi ILM adalah menciptakan komunikasi persuasif yang dapat mempengaruhi target adopter untuk merubah perilakunya sesuai dengan keinginan pemasar sosial (Nisa, 2015)

Iklan dipilih karena melihat efektifnya media TV, video share melalui media social seperti whatsapp sebagai sarana media yang menunjang penyebaran iklan itu sendiri. Hampir dapat dikatakan bahwa masyararakat Indonesia saat ini tidak asing dalam menggunakan media tersebut. Hal ini tercermin dari survei Nielsen Consumer Media View (CMV) yang menunjukkan bahwa penetrasi televisi yang diwakili oleh 11 kota di Indonesia mencapai 96 persen.

Penelitian ini akan memproduksi video berstandard televisi yang jukan akan di share melalui Whatsapp dan Youtube menggunakan teori pembuatan ILM dari Setiawan (2015) berbasis strategi kreatif yaitu 1) pendekatan isi pesan, 2) what to say dan 3) how to say. Untuk mengumpulkan temuan dari hasil dampak iklan layanan masyarakat kepada kesadaran membayar zakat, maka dilaksanakan pendistribusian kuesioner kepada masyarakat yang disesuaikan dengan kuesioner riset sebelumnya yang telah dilakukan oleh Mukhlis dan Beik (2013).

\section{Kajian Teori}

\section{Theory of Planned Behavior}

Teori ini yang awalnya dinamai Theory of Reasoned Action (TRA), dikembangkan di tahun 1967, selanjutnya teori tersebut terus direvisi dan diperluas oleh Icek Ajzen dan Martin Fishbein. Ada beberapa tujuan dan manfaat dari teori ini, antara lain adalah untuk meramalkan dan memahami pengaruh-pengaruh motivasional terhadap perilaku yang bukan dibawah kendali atau kemauan individu sendiri. (Achmat, 2010). Sedangkan munculnya niat untuk berperilaku ditentukan oleh tiga factor sebagaimana dijelaskan oleh Mustikasari (2007), yaitu: 1) keyakinan tentang hasil perilaku dan evaluasi terhadap hasil perilaku (behavior 
belief), 2) keyakinan tentang harapan normatif dari orang lain dan motivasi untuk menuruti harapan tersebut (normative belief), serta 3) keyakinan tentang faktor yang mendukung dan menghambat perilaku (control belief). Niat (intention) untuk berperilaku dapat diprediksi dari sikap (attitude), norma subjektif (subjective norm), dan persepsi atas kontrol perilaku (perceived behavior control). Suatu perilaku (behavior) dapat diukur dengan baik disebabkan deteksi dari sikap (attitude), norma subjektif (subjective norm), dan persepsi atas kontrol perilaku (perceived behavior control), berdasar indikator yang sama atau mendekati kesamaan.

\section{Zakat}

Zakat menurut bahasa berarti al-barakatu: keberkahan, al-namaa,: pertumbuhan dan perkembangan, ath-thaharatu: kesucian, ash-shalahu: keberesan. Didalam buku Fathul Qorib yang diterjemahkan oleh Amar (1983: 158) terdapat definisi zakat bahwa secara syara' zakat adalah nama bagi suatu harta tertentu, menurut cara-cara tertentu, kemudian diberikan kepada sekelompok orang yang tertentu pula. Di Indonesia, pengelolaan zakat telah diatur dalam Undang-undang No.38 tahun 1999. Dengan kata lain, peraturan perundang-undangan tentang zakat sebenarnya sudah ada sejak tahun 1999 lamanya.

Di bawah ini terdapat pandangan zakat secara istilah yang dikemukakan oleh pemuka agama di dalam buku-bukunya: 1) Zakat adalah bagian dari harta dengan persyaratan tertentu, yang Alloh SWT mewajibkan kepada pemiliknya untuk diserahkan kepada yang berhak menerimanya, dengan persyaratan tertentu pula (Hafidhuddin, 2002).; 2) Rahman (2010: 148) mendefinisikan bahwa zakat adalah mengeluarkan sebagian harta yang telah mencapai batas waktunya (nishab) untuk diberikan kepada orang yang berhak menerimanya (mustabiq) sesuai dengan ketentuannya; 2) Menurut pandangan Yusuf (2004) zakat adalah bagian dari pendapatan dan kekayaan mereka yang berkecukupan yang menjadi hak mereka yang berhak.

Jika harta sudah sesuai dengan batas waktu (haul) dan ukurannya (nishab) yang telah ditentukan di dalam syara', maka 
zakat wajib dikeluarkan. Zakat dibagi atas dua macam diantaranya zakat fitrah dan zakat mal. Zakat fitrah adalah zakat yang berupa bahan makanan yang diberikan saat idul fitri, sedangkan zakat mal adalah zakat harta benda.

\section{Teori Komunikasi dan Iklan Layanan Masyarakat}

Komunikasi adalah proses pertukaran informasi di antara individu melalui sistem, lambang-lambang, tanda-tanda atau tingkah laku. Sementara itu Nuruddin (2004) mengemukakan bahwa komunikasi adalah proses dimana suatu ide dialihkan dari sumber kepada satu penerima atau lebih dengan maksud mengubah perilaku. Komunikasi juga dapat dipahami sebagai proses penyampaian informasi menggunakan lambang-lambang yang mengandung arti atau makna, baik secara verbal maupun nonverbal dari seseorang kepada orang lain untuk mencapai saling pengertian. Proses komunikasi secara sederhana dapat digambarkan dengan model SMCR yaitu sumber (Source) mengirim pesan (Message) melaui saluran (Channel) kepada penerima (Receiver).

Menurut Anwar (1997), Agar proses komunikasi dapat mencapai sasarannya, maka perlu diperhatikan hal-hal sebagai berikut: 1) Adanya ide yang jelas, 2) Pemeriksaan tujuan komunikasi, 3) Lingkungan fisik dan manusia sebelum melakukan komunikasi, 4) Isi dan nada suara, 5) Konsultasi kepada pihak lain dan dukungan, 6) Nilai dari komunikasi, 7) Tindak lanjut, dan 8) Kepadatan informasi (singkat dan jelas)

Sebagaimana dikutip oleh Setiawan (2015) dari Pujiyanto (2014) iklan Layanan masyarakat adalah jenis iklan yang digunakan untuk menyampaikan informasi, mengajak, atau mendidik khalayak dimana tujuan akhirnya bukanlah untuk mendapatkan keuntungan ekonomi, melainkan keuntungan sosial lewat pengetahuan, kesadaran, sikap, dan perubahan perilaku masyarakat. Iklan Layanan masyarakat didasari oleh kondisi lingkungan dan perilaku yang berdampak pada permasalahan sosial. ILM yang baik adalah iklan yang dapat membuat target adopternya mengapresiasi iklan tersebut dan meresapi pesan yang disampaikan. 


\section{Sampel dan Metode Penelitian}

Populasi yang diambil dalam penelitian ini adalah seluruh masyarakat muslim yang memiliki penghasilan tetap di daerah Jawa Tengah dan Yogyakarta. Dikarenakan jumlah masyarakat muslim yang memiliki penghasilan tetap di daerah Jawa Tengah dan Yogyakarta terhitung tidak sedikit, maka dalam riset ini ditentukan sampel yang didasarkan atas kritreria Slovin (1960) atau yang dikenal degan istilah random sampling (Sarwono, 2006). Karena dikehendaki dengan batas toleransi sebesar $0,1 \%$, maka sejumlah 200 respondenlah yang mengisi dua jenis kuesioner. Jenis analisa yang dipakai adalah bentuk analisa regresi linier.

\section{Hasil Temuan Studi}

\section{Gambaran Demografi Jawa Tengah dan Yogyakarta}

Jumlah pendudukJawa Tengah terdiri atas 32 juta penduduk. Dari jumlah penduduk, mata pencaharian yang banyak adalah di sektor pertanian $(42,34 \%)$, diikuti dengan perdagangan $(20,91 \%)$, industri $(15,71 \%)$ dan jasa (10,98\%). Jumlah penduduk tersebut berdasarkan Data statistik yang sudah dirilis BPS. Jumlah muslimnya terhitung besar mencapai angka 572.517 di tahun sensus 2010. Sementara itu, daerah Istimewa Yogyakarta adalah salah satu kota di Indonesia yang memiliki jumlah penduduk terbanyak keempat setelah Pulau Jawa bagian selatan seperti Bandung, Malang dan Surakarta. Kota Yogyakarta terletak $600 \mathrm{Km}$ dari Jakarta, $116 \mathrm{Km}$ dari Semarang, dan $65 \mathrm{~km}$ dari Surakarta. Sementara itu, jumlah penduduk Yogyakarta terdiri atas 400 ribu penduduk. Jumlah muslimnya yang dirilis dari data kepemerintahan Yogyakarta mencapai angka 335.521di tahun sensus 2014.

Hasil Statistik Pengaruh Video Iklan Layanan Masyarakat terhadap Kesadaran Berzakat Masyarakat Jawa Tengah dan Yogyakarta

Setelah dilakukan uji normalitas, heteroskendastisitas dan multikolinieritas dan dinyatakan lolos, maka dengan bantuan program statistik SPSS 16, diperoleh rangkuman sederhana hasil 
regresi linier seperti pada tabel di bawah ini.

Tabel 2. Hasil Koefisien Determinasi

\begin{tabular}{lllll}
\hline \multicolumn{4}{c}{ Model Summary } \\
\hline Model & $\mathrm{R}$ & $\mathrm{R}$ Square & Adjusted R Square & Std. Error of the \\
1 & $.443^{\mathrm{a}}$ & .196 & .192 & 15.993 \\
a. Predictors: (Constant), KESADARAN_BERZAKAT
\end{tabular}

Nilai hubungan (R) dari tabel di atas adalah sebesar 0,443 . Koefisien determinasi $\left(R^{2}\right)$ yang ditunjukkan pada tabel SPSS di atas adalah sebesar 0.192 . Secara jelasnya maka ditemukan adanya pengaruh sebesar 19,2 \% antara video iklan layanan masyarakat terhadap kesadaran berzakat masyarakat Jawa Tengah dan Yogyakarta.

\section{Tabel 3. Hasil F Hitung}

\begin{tabular}{lllllll}
\hline \multicolumn{7}{c}{ ANOVA $^{\mathbf{b}}$} \\
\hline Model & & Sum of Squares & Df & Mean Square & F & Sig. \\
1 & Regression & 13230.727 & 1 & 13230.727 & 51.730 & $.000^{\text {a }}$ \\
& Residual & 54221.918 & 212 & 255.764 & & \\
& Total & 67452.645 & 213 & & &
\end{tabular}

a. Predictors: (Constant), KESADARAN_BERZAKAT

b. Dependent Variable: PERSEPSI_VIDEO

Tabel di atas menunjukkan adanya pengaruh yang signifikan antara video iklan layanan masyarakat terhadap kesadaran berzakat.

Tabel 4. Hasil Analisa Regresi Linier

\begin{tabular}{|c|c|c|c|c|c|}
\hline \multicolumn{6}{|c|}{ Coefficients $^{\mathrm{a}}$} \\
\hline & Unstand & ardiz & Standardized & & \\
\hline Model & Coefficients & & Coefficients & & \\
\hline B & Std. Error & Beta & & $\mathrm{t}$ & Sig. \\
\hline (Constant) & 61.654 & 8.900 & & 6.928 & .000 \\
\hline $\begin{array}{l}\text { KESADARAN_BERZAKAT } \\
\text { a. Dependent Variable: PERSE }\end{array}$ & $\begin{array}{l}.539 \\
\text { PSI VIDEO }\end{array}$ & .075 & .443 & 7.192 & .000 \\
\hline
\end{tabular}


setelah menyaksikan video iklan layanan masyarakat. Adapun hasil dari 0.539 merupakan koefisien regresi yang menunjukkan dimana setiap ada penambahan 1 angka untuk persepsi video iklan layanan masyarakat, maka akan ada kenaikan atas kesadaran berzakat sebesar 0.539

Variabel video iklan layanan masyarakat (X) mempunyai pengaruh positif terhadap kesadaran berzakat $(\mathrm{Y})$ dengan koefisien regresi sebesar 0.539 Ini menunjukkan pula jika video iklan layanan masyarakat di tayangkan maka kesadaran berzakat masyarakat adalah sebesar 0.539 dengan asumsi variable bebas yang lain konstan. Nilai signifikansi (sig) sebesar 0.000, jauh lebih rendah jika dibandingkan dengan $(0,05)$. Oleh karena itu pengaruh video iklan layanan masyarakat terhadap kesadaran berzakat masyarakat jawa tengah adalah signifikan.

\section{Hasil Persepsi Video Iklan Layanan Masyarakat}

Bagian dari hasil persepsi atas video iklan layanan masyarakat ini terbagi ke dalam kategori yang deskripsinya tercantum di bawah ini. Secara garis besar kategorinya terbagi atas 1) Tema 2) Format 3) Ide dan Tujuan 4) Kesan dan 5) Rencana.

\section{Tema Video}

Berdasarkan uraian jawaban yang dituliskan oleh masyarakat Jawa Tengah dan Yogyakarta bahwa mayoritas sudah mendapati kecocokkan maksud dari tema yang digagas di dalam video iklan layanan masyarakat. Zakat dan berbagi adalah tema yang memang sengaja diangkat dan di akhir alur video pun juga sudah dijelaskan bentuk secara visual terkait tulisan zakat. Dibawah ini adalah penggalan tulisan responden terhadap kecocokan tema studi ini

"Kewajiban berzakat bagi umat islam"

"Menjalin hubungan dengan Allab dan Manusia"

"Kesadaran Zakat Seorang Muslim" 


\section{Ide dan Tujuan}

Video iklan layanan masyarakat yang sudah disaksikan oleh masyarakat Jateng dan Yogyakarta menghasilkan temuan positif atas ide dan tujuan dari video. Di dalam video iklan layanan masyarakat memang mengandung bahasa persuasif untuk mendorong muslim melaksanakan zakat. Mayoritas mengemukakan kata-kata ajakan berzakat di dalam kolom komentar uraian atas video. Bahasa persuasif yang sampai secara baik kepada masyarakat dalam bentuk respon yang seperti itu menjadikan zakat itu bukan sekedar pengetahuan bagi mereka tetapi juga ajakan untuk sesegera dan sesadar mungkin untuk menyisihkan hartanya. Respon di bawah ini adalah satunya: "Maksud video: mengajak berzakat"

Secara umum masyarakat merespon bahwa tujuan video yang telah mereka saksikan tergolong ke dalam video yang mengedukasi dan mempengaruhi. Sedikit yang mengutarakan bahwa video tersebut tergolong video yang menghibur. Dan inilah yang memang benar-benar dicari dari studi ini bahwa masyarakat saat ini membutuhkan konsumsi tayangan yang menambah kedalaman pengetahuan mereka. Video iklan layanan masyarakat diharapkan bukanlah sekedar video yang memenuhi kebutuhan hiburan tetapi lebih ditekankan kepada edukasi yang berbobot.

Beberapa mendapati pesan pesan yang terkandung secara tersirat dari video iklan layanan masyarakat yang sudah disaksikan. Mereka menulis secara umum Jawa Tengah dan Yogyakarta belum dapat dikatakan sebagai masyarakat yang peduli akan sesama muslim yang lain. Ada juga yang menuliskan bahwa memang tidak bisa dipungkiri bahwa masyarakat mayoritas masih tertekan oleh hawa nafsu untuk memenuhi apa yang diinginkannya sendiri tanpa memperhatikan keadaan sekitarnya. Dan di bawah ini adalah tanggapannya:

"Dalam video tersebut ditampilkan babwa masib banyak masyarakat yang kurang peduli tentang sesama sesama terutama zakat, karna dengan zakat artinya kita mensyukuri nikmat yang telah Allab berikan." 
Beberapa memberikan kesan terhadap video bahwa kesadaran akan zakat yang mensucikan terbentuk setelah menyaksikan video

"Saya merasa tersadarkan setelah melihatnya babwa berzakat itu dapat membersibkan harta yang dimiliki"

Selain menanggapi dalam bentuk pesan diatas, masyarakat Jawa tengah dan Yogyakarta memberikan masukan nilai-nilai yang terkandung di dalam video iklan layanan masyarakat yang telah disaksikan. Mereka menulis bahwa video iklan layanan masyarakat yang mengambil tema zakat berisi tentang ajaran akan tegaknya nilai agama dan kemanusiaan secara selaras. Sering didapati di dalam komentar mereka bahwa mereka selalu mengambil nilai ta'awun (tolong-menolong sesama) dan rasa iba akan fakir miskin yang memiliki masalah pelik dalam memenuhi kebutuhan hariannya.

"Nilai kemanusiaan: Berbagi dan tolong menolong dalam kebaikan"

Hal menarik yang dapat ditarik pada temuan ini bahwa beberapa responden mengutarakan konsep ikhlas yang sejatinya sangat susah terdefinisikan. Ikhlas sangat sukar didefinisikan karena nilai dari diterimanya adalah bergantung pada Allah SWT semata. Boleh jadi setelah melaksanakan zakat memang tidak menyebut-nyebut di depan umum bahwa sudah melaksanakan zakat, tetapi rasa riya (pamer) dan ujub (bangga yang berlebihan) dari dalam diri sendiri menyebabkan berkurangnya nilai ikhlas itu sendiri.

"Nilai Agama: Ikblas"

Kesimpulan yang dapat ditarik dari video iklan layanan masyarakat menurut responden adalah nilai kewajiban zakat sebagai ibadah dan ditekankannya kepedulian sosial. Mayoritas menyebutkan kalimat bahwa zakat itu wajib.

"Zakat itu wajib"

"Membantu orang lain itu penting" 


\section{Format}

Masukan yang terkumpul atas video iklan layanan masyarakat tentang zakat pada bagian formatnya adalah 1) ketersediaan pengisi suara, 2) durasi, 3) pemeran dan 4) latar belakang video.

Menilik dari segi sisi audio mayoritas mengedepankan istilah dubbing untuk suaranya. Jika lebih dipahami, yang mereka sebut dengan dubbing adalah ketersediaan pengisi suara yang membacakan teks yang ada di dalam video. Ini adalah temuan yang membangun dan menjadi hal utama yang akan dipertimbangkan dari segi format video. Memang dengan adanya audio teks akan membantu masyarakat dalam mengambil pesan dari video tersebut dibandingkan dengan membacanya.

"Dabing agar bisa memperjelas"

Untuk durasi video iklan layanan masyarakat tentang zakat, secara umum masyarakat tidak memiliki masalah dari segi durasi video. Ini karena mereka mayoritas mereka mengiginkan video iklan yang tidak terlalu panjang dalam artian tidak lebih dari 5 menitan.

Dari segi latar belakang video, setiap responden masyarakat Jawa Tengah dan Yogyakarta memiliki masukan yang berbedabeda untuk hal tersebut. Di dalam studi ini dipilihlah respon yang paling padat dan mendekati maksud dari nilai zakat secara agama dan sosial.

"Tampilkan gambaran neraka dengan efek budaya manusia yang semakin bilang empati dan rasa peka sosialnya, dan keadaan bumi yang bertambah tua ditambah ulah manusianya yang serakah memperburuk keadaan, terakhir kematian itu menunggu mu lalu apakah kamu sudah berzakat?"

Selain respon latar belakang di atas, beberapa juga memberikan saran untuk tersedianya latar belakang yang mengandung human sense bagi pemirsa yang menyaksikan video iklan layanan masyarakat. 
"Mungkin bisa menampilkan manfaat dari zakat ketika sudab ditunaikan dan disampaikan kepada si penerima zakat ternyata bisa membantu meringankan beban hidup mereka (buman sense)"

Beberapa menanggapi beberapa pendukung tentang latar belakang video yang juga dikaitkan tidak hanya pada mengedepankan pemeran mustabiq dengan keadaan kemiskinan yang dihadapinya. Latar belakang yang diharapkan dari masyarakat bahwa latar yang terkait juga terkait dengan yayasan islam juga; atau lembaga-lembaga yang biasanya sangat umum dengan kegiatan sosial berupa penyaluran sebagian harta seperti sedekah.

"Tidak hanya sekedar mengambil gambar pengemis tapi juga semacam yayasan madrasab atau mesjid atau pembangunnan fasilitas Islam lainnya sebagai pendukung kegiatan yang berkaitan dengan zakat."

Ada tambahan yang disampaikan terkait saran pemeran dan budaya yang dapat menjadi masukan untuk diperbaiki kedepannya. Mayoritas responden mengiginkan kesesuaikan budaya dari segi kostum yang dipakai oleh pemeran. Hendaknya kostum disesuaikan dengan suasana yang digambarkan di dalam video.

"Kostum yang perlu disesuaikan lagi dengan peran yang akan dibawa."

"Shalat pakai celana jins, pemulung bajunya bagus"

Dari segi warna yang diusung di dalam latar belakang video iklan layanan masyarakat, beberapa menuliskan untuk adanya perbaikan dari segi pengaturan kontras warna di salam video. Ini dikarenakan beberapa responden yang menyatakan bahwa mereka kesulitan membaca pesan tertulis yang ada di dalam iklan karena warnanya kurang tajam terlihat.

Kesadaran Berzakat Masyarakat Jawa Tengah dan Yogyakarta

Hasil dari kesadaran berzakat di dalam bagian ini terbagi atas 4 yaitu 1) behavioral beliefs, 2) normative belief, 2) control belief, dan 3) intention (niat) 
Keyakinan Sikap (Behavioral Beliefs) atas Zakat

Behavioral beliefs merupakan keyakinan individu akan hasil dari suatu perilaku dan evaluasi atas hasil tersebut (Ajzen, 2005). Keyakinan ini berasal dari diri sendiri. Sehingga jika masyarakat berzakat maka itu adalah dikarenakan dari diri sendiri. Behavioral belief atas zakat yang mendominasi dari jawaban responden adalah keyakinan atas iman, rasa mampu, dan keyakinan bahwa akan ada hasil baik berupa tambahnya rizki. Dibawah ini adalah salah satu penggalan respon dari masyarakat Jawa Tengah dan Yogyakarta:

"Allab tidak akan membuat kita jatuh miskin karena beramal tetapi Allab akan menaikan drajat kita esok di yaumul qiyamab"

"Saya percaya kalo Rizki Allab yang mengatur dan apa bila kita berzakat maka akan di beri Rezki yang lebib"

Keyakinan Normatif (Normative Beliefs) atas Zakat

Normative beliefs yaitu keyakinan tentang harapan normatif orang lain dan motivasi untuk memenuhi harapan tersebut (Ajzen, 2005). Rasa iba akan fakir miskin, dan analisa responden sendiri bahwa masih ada mustahiq yang perlu dibantu adalah respon dari normative beliefs yang ditulis oleh responden. Selebihnya beberapa menyatakan bahwa mereka didorong serta di dorong untuk berzakat oleh keluarga dan kerabat yang menunaikan zakat.

"Motivasi saya untuk menunaikan zakat adalah mengingat dan melihat kesengsaraan orang miskin"

"Warga menyambut dengan baik jika saya menunaikan zakat dan orang tua saya senang jika saya menunaikan zakat serta Allah bangga dengan hambanya yang sadar akan zakat" 
Keyakinan Mendukung dan Menghambat (Control Beliefs) atas Zakat

Control beliefs merupakan keyakinan tentang keberadaan hal-hal yang mendukung atau menghambat perilaku yang akan ditampilkan dan persepsinya tentang seberapa kuat hal-hal yang mendukung dan menghambat perilakunya tersebut atau dikenal dengan perceived power (Ajzen, 2005). Hal yang menghambat dan disebut secara sering dalam kesadaran zakat masyarakat Jawa Tengah dan Yogyakarta adalah adanya hutang. Memang sering disebut, tetapi dari hasil temuan bahwa hal ini tidak menjadi penghalang kesadaran mereka untuk berzakat. Mereka tetap yakin bahwa lebih besar hal-hal yang mendukung zakat dibandingkan yang menghalanginya.

\section{Niat (Intention)}

Suatu perilaku (behavior) dapat diukur dengan baik disebabkan deteksi dari sikap (attitude), norma subjektif (subjective norm), dan persepsi atas kontrol perilaku (perceived behavior control), berdasar indikator yang sama atau mendekati kesamaan. Sehingga niat ada karena keyakinan positif beriringan (Ajzen, 2005).

Jadi seiring dengan tiga beliefs diatas, maka niat responden yang sudah mereka tuliskan terkait adanya pertanyaan 'sadar zakat': "Adakah rencana Anda untuk berzakat? Jika ada, jelaskan bagaimana zakatnya akan disalurkan?” tertera di bawah ini:

"Ada. Melalui laziz Muhammadiyab"

"Ada. Akan disalur ke seseorang yang membutubkan secara langsung"

"Skala prioritas... pertama saya salurkan pada masyarakat terdekat..."

Beberapa responden diatas menulis bahwa mereka merencanakan zakat yang akan disalurkan secara mandiri. Ada juga yang berencana menunaikan zakat dengan bantuan badan amil zakat. Bahkan ada yang mengutamakan lingkungan sekitar yang 
terdekat terlebih dahulu. Yang menjadi persoalan pada temuan niat bahwa mayoritas masyarakat di Jawa Tengah dan Yogyakarta merencanakan zakat yang jenisnya adalah fitrah. Dan tidak dapat dikatakan bahwa mayoritas berencana melaksanakan Zakat mal, walaupun beberapa menyebutkan rencana

\section{Kesadaran Berzakat sebagai Keseimbangan Ibadah}

Di Indonesia sendiri Badan Pusat Statistik Indonesia merilis hasil data kemiskinan bahwa di September 2017 mencapai angka 26,58 juta orang. Mendapati nilai yang seperti itu, maka perlulah sebaiknya yang dimaksud kepedulian sosial ditingkatkan. Inilah hasil ukuran sebenar-benarnya yang bisa dipergunakan untuk kesempatan beribadah secara sosial, khususnya dalam studi ini adalah kesadaran berzakat masyarakat Jawa Tengah dan Yogyakarta.

Allah sudah melimpahkan karunia yang sejatinya luar biasa besar bagi makhluknya. Meski beberapa sering tidak menyadarinya baik itu berupa fisik mulai dari harta benda hingga yang tak terlihat (non fisik) seperti diberikannya akal yang sehat dan kesehatan untuk menjalani kegiatan sehari-hari. Tentang karunia berupa kekayaan, Islam mengajarkan kepada manusia untuk tidak hanya menerima tetapi juga memberi. Tidak hanya memperoleh tetapi juga membagikannya. Disinilah letak relevansi agama Islam dari yang namanya zakat, infaq, shadaqah.

Allah juga dengan tegas menyerukan agar jangan sampai terjadi konsentrasi kekayaan disekelompok masyarakat, sementara yang lainnya hidup di dalam kekurangan (QS. 59: 7). Islam tidak menghendaki adanya sistem kapitalisme dimana setiap individu mempunyai kekuasaan hak penuh terhadap hartanya, serta bebas menggunakan sumber-sumber ekonomi menurut cara yang dikehendakinya. Setiap individu beehak memperoleh manfaat dari produksi dan distribusi kekayaanmya. Di dalam kondisi seperti itu, persaingan bebas tidak dianjurkan di dalam ajaran Islam. Ini semua sebenarnya sudah disadari oleh masyarakat Jawa Tengah dan Yogyakarta karena beberapa respon mereka juga tertulis bahwa terdapat sebagian harta fakir miskin yang harus dizakati. 
Terlebih lagi di dalam Al-Quran yang menjadi pedoman bagi muslim, perintah zakat sering disandingkan dengan perintah shalat. Setidaknya terdapat 24 tempat ayat Al-Quran yang menyebutkan shalat dan zakat secara bergandengan. Ini menandakan bahwa shalat sebagai ibadah manusia dengan Tuhannya tidak bisa terlepas dari keharusan untuk peduli kepada kondisi masyarakat sekitarnya. Dengan kata lain, muslim sejati adalah muslim yang senantiasa memprioritaskan secara beriringan antara ibadah individu dan ibadah sosial.

Ajaran Islam sendiri lekat dengan aturan yang mengaitkan hubungan dengan Sang Pencipta hablumminalloh, tetapi juga hablumminannas. Zakat bukan hanya sekedar kewajiban agama (teologis) untuk membersihkan harta milik tetapi juga kewajiban sosial untuk menyalurkan sebagian harta kepada penerima zakat (mustabiq). 'Zakat itu wajib' yang menjadi kesimpulan yang diutarakan mayoritas muslim di Jawa Tengah dan Yogyakarta menjadi gambaran bahwa behavioral belief atas zakat ini tetap ada di dalam jiwa mereka. Mereka memahami zakat itu secara agama memang hal yang wajjib dan berdosa jika ditinggalkan.

Beruntunglah bagi sifat muslim yang mau berkorban dan tidak merasa berat hati dalam menyisihkan hartanya. Sebab jika dirujuk dari Al-Quran (QS Al-Imran: 134) menjelaskan bahwa sifat orang yang bertaqwa adalah orang yang rela menyisihkan hartanya baik dalam keadaan suka maupun duka. Kualitas ketaqwaan ini menjadi sempurna jika salah satunya zakat ini disadari oleh masyarakan dan ditunaikan. Di dalam studi ini, masyarakat Jawa Tengah dan Yogyakarta merespon positif akan tema zakat yang ditampilkan di dalam video iklan layanan masyarakat.

Zakat sendiri yang menurut arti bahasa berkembang dan suci menjadi penegas bahwa dari zakat yang telah dilaksanakan maka manusia dapat menjadi insan yang progresif dalam kehidupannya atau menjadi maju dan berkembang (Amar, 1983). Selain itu, dari zakat yang telah dikeluarkan diharapkan manusia menjadi bersih dari segala sifat-sifat negatif seperti ketamakan akan harta yang dimiliki, kikir dan ketidak pedulian atas kesenjangan yang terjadi di sekitarnya. 
Salah satu motivasi zakat yang sudah dituliskan oleh beberapa masyarakat Jawa Tengah dan Yogyakarta sudah mengaitkan adanya rasa iba dan rasa peduli akan keadaan sosial di sekitarnya. Sebenarnya mayoritas dari mereka memandang kesenjangan sosial adalah faktor yang harus diupayakan untuk dirubah menjadi lebih baik dengan cara mengurangi beban fakir miskin melalui menyisihkan harta benda mereka.

Zakat juga diartikan sebagai 'tumbuh' dan 'berkembang', dimana sebenarnya jika dijabarkan dapat dilihat dari dua sisi. Sisi petama dari orang yang berzakat (muzakki), maka Allah SWT menjanjikan balasan ganjaran yang berlipat (QS. Al-Baqarah: 261). Rasulullah juga bersabda bahwa harta tidak akan menjadi berkurang karena bersedekah (HR. Tirmidzi). Dari sisi kedua yaitu sisi orang yang menerima zakat (mustahiq), maka jelas jika zakat mengembangkan harta yang dimilikinya berupa bertambahnya pendapatan. Bahkan dengan zakat maka kondisi seseorang yang nantinya menjadi sedih karena berkekurangan menjadi lebih tenang dan bersyukur (QS.At-Taubah, 103). Keyakinan masyarakat Jawa Tengah dan Yogyakarta terhadap bertambahnya nilai harta ketika berzakat memang sudah disadari di dalam studi ini.

Gurning dan Ritonga (2015) memerikan gambaran melalui risetnya bahwa di daerah Medan Baru, tingkat kesadaran zakat masyarakatnya masih dapat dibilang sangat baik untuk kategori zakat fitrahnya. Terdapat beberapa faktor-faktor utama yang mempengaruhi tingkat kesadaran zakat yang sejalan dengan penelitian ini diantaranya behavioral belief yang berupa tingkat pemahaman zakat, normative belief (tingkat kepedulian sosial dan faktor respon bagi muzakki), control belief (ketersediaan informasi tentang zakat dan layanan zakat).

Di daerah Bogor, Jawa Barat sendiri juga sudah dilaksanakan sebuah riset dari Mukhlis dan Beik (2013), dimana ditemukan bahwa salah satu faktor zakat yang berupa pujian (normative belief dipandang menjadi faktor yang meiliki tingkat paling rendah dalam terhadap sadarnya zakat masyarakat Bogor. Tidak jauh dari sekitar Jawa Barat bahwa Kurniawati dan Sukma (2015) mendapati bahwa mayoritas masyarakat Sukabumi dalam mengeluarkan zakat dipengaruhi oleh faktor utama diantaranya psikologi dan sosial 
Hasil yang telah dianalisa oleh Huda dan Ghofur (2012) yang melibatkan masyatrakat DKI Jakarta mengindikasikan bahwa secara bersama-sama antara variable sikap, nnorma subjektif, kendali perilaku, penghasilan, pendidikan dan pengetahuan memiliki pengaruh yang signifikan terhadap intensi (niat) muzakki. Melihat sedikit ke antar negara seperti Malaysia, bahwa mayoritas masyarakatnya mengeluarkan zakat atas dasar faktor utama yang disebut dengan keimanan. tetapi memang belum sampai pada tataran mencari tahu tingkatan bertambahnya kesadaran dengan pengaruh-pengaruh lainnya (Muda et al, 2006). Inilah yang menjadi tambahan sebagai pendukung dalam riset ini dimana semua pengaruh tersebut dicoba dihubungan dengan persepsi setelah menonton iklan layanan masyarakat. Hasilnya juga tidak mengecewakan karena sebesar 19,6\% kesadaran zakat masyarakat Jawa Tengah dan Yogyakarta dipengaruhi oleh media iklan layanan masyarakat.

Melalui zakat, maka rasa empati khususnya cinta kasih seorang muslim terhadap kaum yang lemah juga akan meningkat. Perasaan partisipasi intuitif terhadap kaum miskin dari muzakki pada saat berzakat menjadi dikuatkan dan tanggung jawab dibangkitkan. Pengorbanan berupa harta yang dikeluarkan oleh muzakki menjadikannya lapang dada dan lega jiwanya. Muzakki akan merasa dicintai oleh Tuhannya dan saudaranya yang berkekurangan.

Inilah Islam yang komprehensif, dimana pengakuan hak individu dan kolektif itu ada secara bersamaan. Membayar zakat bukan berarti berpihak pada yang miskin. Maksudnya bahwa dari harta orang yang kaya itu bukan milik sepenuhnya, melainkan milik Allah SWT yang diamanatkan. Pernyataan ini bahkan di dalam studi ini sudah mampu disinggung oleh beberapa masyarakat Jawa Tengah dan Yogyakarta. Mereka memahami bahwa si kaya harus membelanjakan hartanya menurut persyaratan amanah dan salah satunya adalah memenuhi kebutuhan orang lain yang sejalan dengan perintah yang difirmankan Allah melalui QS.Al Hadid ayat 7.

Aturan zakat di dalam Islam sendiri mengatur bahwa tidak sembarang orangyang akan dapat menerima zakat, dimana ada yang 
dinamai dengan golongan-golongan yang berhak mendapatkan zakat. Namun, di dalam studi ini, juga masih didapatkan beberapa keraguan dalam berzakat yang dihasilkan dari masyarakat Jawa Tengah dan Yogyakarta karena ketidak tahuan akan siapa-siapa yang benar-benar berhak menerima zakat.

Zakat memiliki sisi pembelajaran memberi. Memberi di dalam Al-Quran tergolong akhlak yang terpuji dan selalu dikaitkan dengan kadar iman taqwanya seorang muslim (QS. Al-Baqarah, 1-3). Zakat jika boleh ditambahkan maka menjadi bentuk upaya menjaga, yaitu menjaga niat jahat dari si mustahiq dan muzakki. Mustabiq melalui diterimanya zakat maka tidak dihantarkan untuk melakukan tindakan negatif lainnya.

Zakat adalah upaya memperluas peredaran harta bilamana harta disalurkan, maka banyak orang yang dapat memanfaatkannya. Manfaat ini menunjukkan perkara kemaslahatan umat dimana harta beredar dan tidak hanya menjadi harta yang dimonopoli secara sendiri oleh orang kaya. Semakin banyak harta yang disisihkan kepada banyak fakir miskin yang membutuhkan, maka semakin berkah dan berputar secara bermanfaat atas harta yang dimiliki. Bahcmid (2012) mendapati di dalam studinya bahwa perilaku orang yang berzakat mengedepankan nilai spriritual yang sejalan dengan ekonomi, dan sosial. Zakat yang ditunaikan secara konsisten adalah strategi alternatif dalam rangka mengembangkan harta ke arah yang bermanfaat.

Dengan digalakkannya gerakan sadarberzakat, makaberzakat akan menjadi sarana jaminan sosial dan persatuan masyarakat dalam memenuhi kebutuhan pokok individu, memperkecil rasio kemelaratan dan saling menyia-nyiakan sesama muslim. Zakat yang digalakkan juga sebagai alat penyebaran Islam. Ini terlihat pada pemberian zakat kepada orang yang baru saja masuk Islam (muallaf) agar tetap teguh pada keislaman. Selain jaminan diatas, zakat menjadi sarana untuk membantu melepaskan dari terlilitnya orang yang memiliki hutang (gharim). Zakat menjadi pelindung agar gharim merasa terkurangi bebannya.

Muslim yang belajar untuk memberikan sebagian hartanya adalah bukti kasih sayangnya terhadap saudaranya dalam 
rangka kemaslahatan umat. Ini akan jauh sekali dengan muslim yang berkeinginan untuk mengambil harta orang lain dengan merampas, mencuri, bahkan korupsi. Muslim yang berzakat juga disebut muslim rasional yang turut mementingkan jangka panjang dan pendek dengan cara mencapai keridhoan Allah SWT dalam kekayaan dunianya. Masyarakat Jawa Tengah dan Yogyakarta dalam hal ini sudah memahami bahwa bentuk ibadah zakat ini adalah ibadah yang dikategorikan seimbang antara habluminannas dan hambluminalloh. Ini karena mereka sering menyebut "pahala" dan "balasan dari Allah" di dalam pernyataan sadar zakat mereka.

Masih berkaitan bahwa materi tidak akan lepas dari pembahasan tentang kecintaan terhadap dunia. Kecintaan dunia dapat menjauhkan seorang muslim dari Tuhannya. Kecintaan dunia merupakan lingkaran yang tidak memiliki ujung. Sebenarnya kecintaan dunia dalam bentuk mencari harta yang secara terus menerus di era modern ini menghasilkan kedinamisan dan produktifitas yang baik. Tetapi jika itu terus dipikirkan, maka akan muncul ketidak tenangan dalam diri dan bahkan menjauhkan kesadaran muslim kepada Tuhannya.

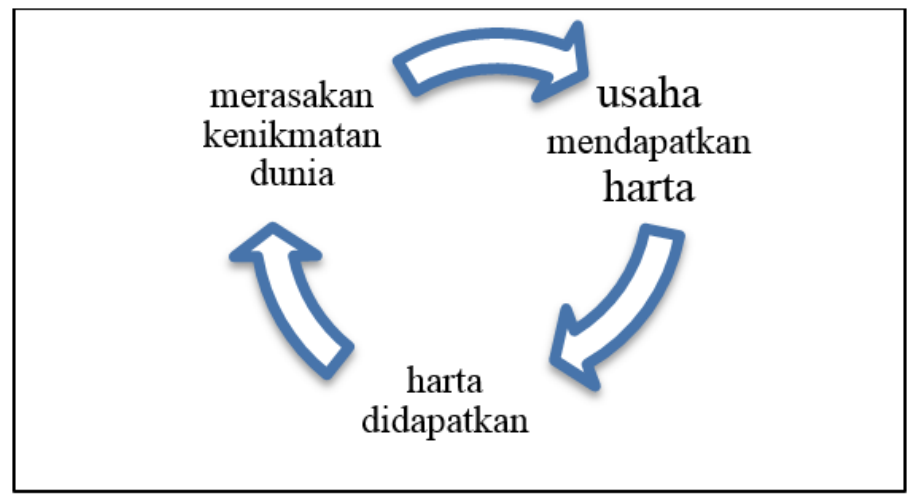

\section{Gambar 2. Skema Kecintaan Dunia}

Ajaran Islam adalah ajaran yang akan memutus lingkaran tersebut. Dengan putusnya lingkaran tersebut berarti seorang muslim berhasil memerangi hawa nafsunya sendiri. Bila harta disertai dengan ujian atau fitnah, maka zakat adalah tameng untuk menandingi fitnah dan ujian tersebut. Muslim pun berhasil disebut 
dengan muslim yang sederhana dan tidak silau harta (akblaqul karimah).

Hal lain yang masih bersinggungan dengan zakat adalah kesadaran muslim untuk menyisihkan sebagian hasil usaha atau disebut dengan zakat profesi (QS. Al-Baqarah, 267). Zakat profesi atau zakat pendapatan adalah zakat yang dikeluarkan dari hasil pendapatan seseorang atau profesinya apabila sudah mencapai nishab (batas)nya. Terkait dengan profesi yang berisi aspek etos kerja mendasari wajibnya dikeluarkan untuk zakat melalui cara pandangnya. Bahwa bekerja bukan hanya untuk kepentingan dirinya, melainkan juga manifestasi dari amal salih yang memiliki nilai ibadah kepada Tuhan dan tanggung jawab kepada sesama manusia. Masyarakat Jawa Tengah dan Yogyakarta mungkin tidak akan sejauh itu mengkonsep kesadaran berzakat profesi, tetapi jenis zakat ini menjadi zakat yang baik untuk mereka dan mereka tidak ada masalah dari segi keyakinan untuk melakukannya.

Harta yang dikeluarkan dalam berzakat haruslah halal. Artinya cara mendapatkannya bukan dari hal-hal yang dilarang agama. kesadaran atas keyakinan muslim masyarakat Jawa Tengah dan Yogyakarta di bagian ini tidak bisa 100 persen diukur secara ilmiah di dalam studi ini. Bagaimanapun tetap baik jika diutarakan bahwa beberapa muslim yang memiliki harta yang maaf 'haram', masih tetap sadar untuk mengeluarkan zakat.

\section{Peran Media atas Kesadaran Berzakat Muslim}

Studi ini tidak menolak temuan yang telah dilakukan oleh Imron (2013) kesadaran masyarakat dalam mengaplikasikan kaidah-kaidah syariah memang dibutuhkan dan salah satunya melalui penyebaran media informasi baik itu cetak maupun elektronik. Ini dikarenakan temuan kesadaran melalui pengaruh iklan layanan masyarakat dipandang memiliki hasil yang positif dalam studi ini. Ditambah lagi bahwa Syihabudin (2018) di dalam tulisannya juga memandang pentingnya kampanye kesadaran berzakat dalam rangka membina kesadaran muzakki. 
Melalui video iklan layanan masyarakat inilah sebenarnya yang akan menjadi alat bantu (sarana) untuk mengoptimalkan dan mendayagunakan ibadah zakat yang seluas-luasnya. Karena salah satu sisi ajaran Islam yang saat ini dioandang masih jarang untuk ditangani secara serius adalah masalah penanggulangan kemiskinan. Dari hasil studi ini juga tidak dapat dikatakan bahwa seluruh masyarakat Jawa Tengah dan Yogyakarta adalah muslim yang semuanya sadar zakat dan menunaikannya. Hambatanhambatan pasti ada. Seperti dalam hal kesadaran berzakat, masih belum seimbang dengan pemahaman yang memadai tentang ibadah yang satu ini. Terutama pemahaman terhadap jenis dan kadar harta yang wajib dizakati serta alur dari pembayaran zakat yang sesuai dengan aturan syariah. Ditambah lagi bahwa kenyataannya ibadah zakat masih tergantung pada masing-masing individu. Hambatan-hambatan itulah yang nantinya dapat menjadi studi-studi yang bisa dianalisa lebih mendalam melalui studi yang berkaitan dengan zakat ini.

Sosialisasi dan publikasi turut berperan di dalam mempengaruhi kesadaran muslim dalam berzakat. Saat ini, metode massif tidak hanya sebatas memberikan pengumuman saja tetapi juga lewat media hingga kunjungan. Inilah salah satu yang telah dicoba untuk membentuk kesadadaran dengan dibagikannya bentuk iklan layanan masyarakat yang dapat diakses melalui telfon genggam maupun segala perangkat yang berhubungan dengan media massa internet. Riset ini adalah bentuk dari usaha menyelaraskan antara ajaran agama dengan pemanfaatan di era digital saat ini. Bahwa berdakwah tidak hanya sebatas di pengajian dan mimbar tetapi juga berdakwah di segala peluang termasuk secara digital karena dipandang sesuai dengan apa yang sering di hadapi masyarakat saat ini.

Dibuatnya video iklan layanan masyarakat tentang zakat menjadi usaha untuk menepis anggapan muslim bahwa "hasil kerja sendiri" membuat berat untuk menunaikan zakat. Selain itu melalui video ini juga menjadi ikhtiar untuk menepis rasa ingin mengumpulkan kekayaan sebanyak-banyaknya dari diri muslim itu sendiri. Dengan diusungnya gambaran makam di dalam video, maka pemirsanya menjadi tidak berfikir bahwa makin banyak harta 
maka main enak. Karena pada dasarnya semua yang dikumpulkan tidak akan terbawa ketika seorang muslim meninggal. Bahkan dari segi salah satu scene yang memperlihatkan makam menjadi hal yang disebut "paling diingat" oleh beberapa masyarakat Jawa Tengah dan Yogyakarta.

Dari video yang sudah dibuat di dalam studi ini maka yang diinginkan bahwa lembaga-lembaga zakat saat ini yang mulai tumbuh berjamur di tengah-tengah masyarakat ikut terbantu dalam upaya memberikan pencerdasan akan urgensi zakat disamping sekedar mengelola zakat. Hal ini dikarenakan bahwa lembaga zakat haruslah memiliki program dakwah dimana umat Islam harusnya sadar bahwa zakat itu tidak hanya sebatas yang berjenis zakat fitrah.

Dengan segala kelebihan yang ada pada saat ini bahwa membayar zakat itu sebenarnya mudah. Zakat dapat dilakukan secara mandiri, transfer, layanan jemput zakat, maupun datang ke kantor amil zakat terdekat. Jika masih belum mengetahui betul besaran zakat yang dikeluarkan maka tokoh agama di sekitar atau pihak pengelola zakat biasanya dapat memberikan arahan dan pencerahan. Maka di dalam studi ini mayoritas keraguan dalam mengeluarkan zakat baik itu karena tidak mengetahui besaran zakat yang dikeluarkan dan tidak menemukannya amil zakat yang pas menjadi hal yang tidak ditemukan. Mayoritas masyarakat Jawa Tengah dan DIY memandang positif ketika disinggung amil zakat dan kadar zakat yang wajib dikeluarkan.

Bilamana zakat dihubungkan dengan kepemerintahan, maka zakat menjadi salah satu instrumen penunjang ekonomi masyarakat. Dalam instrumen zakat, maka akan terwujud semangat untuk saling tolong menolong (ta'awun). Selain itu zakat mengandung unsur pemenuhan kewajiban individu untuk memberikan tanggung jawab kepada sesama. Oleh karena itulah economy with equity adalah hal yang sangat positif untuk dapat kembali disinggung.

Benang merah dari mayoritas persoalan ekonomi umat Islam adalah bagaimana agar kekayaan bumi dapat dikelola dan terdistribusi dengan adil kepada seluruh umat sehingga tidak ada persaingan yang tidak sehat serta egoisme yang berlebihan. 
Cecep dalam Ishlah (1995) mengungkapkan bahwa pengelolaan zakat di dalam suatu negara hendaknya didukung dengan empat hal diantaranya: 1) Power, kekuatan yang terdukung oleh tokoh penting di Negara, 2) Public relation (hubungan masyarakat) atau dukungan dari tokoh masyarakat, 3.) Politic (lembaga-lembaga politik). 4.) Promotion (pemberitahuan kepada masyarakat) seperti lewat media massa dan lainnya. Dibuatnya video iklan layanan masyarakat yang bertema zakat setidaknya membantu dalam memenuhi kategori ke empat dari dukungan pengelolaan zakat di Indonesia khususnya Jawa Tengah dan Yogyakarta.

Zakat pada akhirnya nanti harus menjadi tipe zakat yang tidak hanya konsumtif tetapi memiliki nilai produktif dimana dana zakat dapat membuka lebar pekerjaan baru, meningkatkan derajat hidup orang miskin untuk tidak selalu berkekurangan. Selain itu diharapkan dengan sadar zakat kemudian pelaksanakannya menjadi ajang untuk dapat merekatkan tali persaudaraan antara si kaya dan si miskin. Lebih jauh pembahasannya bahwa zakat dapat menjadi potensi yang halal untuk pembentukan modal. Modal bagi masyarakat yang membutuhkan nantinya tidak hanya dari pemanfaatan dan pengembangan sumber daya alam tetapi juga berasal dari sebagian harta orang yang mampu. Bagi yang membutuhkan nantinya zakat akan menjadi sarana dalam meningkatkan kualitas sumber daya manusia dan prasarana produksi. Semisal pada kasus seseorang yang memiliki keahlian tetapi mengalami kekurang modal untuk usahanya. Maka dengan zakat, kendala modal fakir miskin teratasi. Jika umat Islam menyadari segala macam manfaat dari zakat yang dikeluarkan, maka potesi yang dibahas sejauh itu pasti akan dapat tercapai.

Dalam rangka membantu pengelolaanya, zakat didasarkan atas berbagai pertimbangan antara lain: 1) untuk menjamin kepastian dan disiplin muzakki dalam membayar zakay, 2) menjaga perasaan rendah diri pada mustahiq apabila berhadalapn langsung dengan muzakki, 3) Untuk mencapai efisiensi, efektifitas, dan sasaran yang tepat dalam penggunaan harta menurut skala prioritas yang ada di suatu tempat, 4) untuk memperlihatkan syiar Islam dan semangat penyelenggaraan negara dan pemerintahan yang islami. Poin keempat tentang syiar inilah yang dikedepankan 
melalui media massa dalam wujud iklan layanan masyarakat. Dan hasilnya adalah positif di dalam studi ini.

Ishlah (1995) yang mengutip dari studi Nuryufa bahwa jumlah penduduk muslim tidak akan berarti apa-apa tanpa dibarengi dengan kesadaran akan kewajibannya untuk ikut menegakkan perekonomian umat Islam, baik melalui zakat, infaq maupun shadaqah. Sekali lagi melalui video iklan layanan masyarakat yang bertema "zakat", maka masyarakat Jawa Tengah dan Yogyakarta mulai sadar bahwa zakat menjadi hal yang harus mereka tunaikan sebagai seorang muslim.

\section{Kesimpulan}

Nilai pengaruh (R) dari tabel statistik studi ini adalah adalah sebesar 0,443. Koefisien determinasi (R2) yang ditunjukkan pada tabel SPSS di dalam penelitian ini menunjukkan angka sebesar 0.192. Secara jelasnya maka ditemukan adanya pengaruh sebesar $19,2 \%$ antara video iklan layanan masyarakat terhadap kesadaran berzakat masyarakat Jawa Tengah dan Yogyakarta. Ini menunjukkan nilai positif yang telah dihasilkan dari produksi video. Memang tidak terlalu besar tingkat signifikansi kesadaran berzakat yang dihasilkan, namun dalam hal ini peran media menjadi hal yang tidak lantas secara mudah diabaikan dalam rangka menggerakkan sadar zakatnya masyarakat Jawa Tengah dan Indonesia.

Teori dari Ajzen (2005) yang dikenal dengan Theory of Reasoned Action (TRA) dipandang tetap relevan sebagai basis analisa kesadaran berzakat masyarakat Jawa Tengah dan Yogyakarta. Setidaknya masyarakat Jawa Tengah dan Yogyakarta memiliki keyakinan untuk melaksanakan zakat yang ditinjau dari respon-respon yang sudah ada. Mereka mampu menjabarkan alasan-alasan dan niat mereka untuk berzakat dengan uraiannya yang satu sama lain bervariasi. Hal menarik yang bisa ditekankan bahwa sebenarnya masyarakat Jawa Tengah dan Yogyakarta sadar bahwa yang hal-hal yang menghambat zakat itu lebih rendah dibandingkan yang mendukung zakat. 


\section{Daftar Pustaka}

Achmat, Z. (2010). Theory of planned behavior, masihkah relevan. Diambil dari: http://zakarija. staff. umm. ac. id/files/20, 10, 12.

Amar, Imron Abu. (1983). Fathul Qorib. Kudus: Menara Kudus. Anwar, Arifin. (1997). Komunikasi dalam Teori dan Praktis. Bandung: Armico

Atkin, C. (2001). Impact of public service advertising: Research evidence and effective strategies. Kaiser Family Foundation, Menlo Park, CA.

Bahmid, G. (2012). Perilaku Muzakki dalam Membayar Zakat Mal (Studi Fenomenologi Pengalaman Muzakki di Kota Kendari). Jurnal Aplikasi Manajemen, 10(2), 425-436.

Effendy, Onong Uchjana. (2002). Dinamika Komunikasi. Bandung: PT.Remaja Rosdakarya.

Gurning, H. R. H., \& Ritonga, H. D. H. (2015). Analisis Tingkat Kesadaran Masyarakat Kecamatan Medan Baru Dalam Membayar Zakat. Ekonomi dan Keuangan, 3(7).

Hadi, S. (2004). Analisis regresi. Jakarta: Andi Press.

Hafidhuddin, D. (2002). Zakat dalam perekonomian modern. Jakarta: Gema Insani

Huda, N., \& Ghofur, A. (2012). Analisis intensi Muzakkî dalam membayar zakat profesi. Al-Iqtishad: Jurnal Ilmu Ekonomi Syariah, 4(2).

Ishlah No. 16/Tahun II, 1994, Jakarta, hal. 8

Kurniawati, N., \& Sukma, A. (2017). Preferensi Masyarakat Kabupaten Sukabumi Dalam Pengambilan Keputusan Membayar Zakat. Jurnal Syarikah: Jurnal Ekonomi Islam, 1(2).

Muda, M., Marzuki, A., \& Shaharuddin, A. (2009). Factors influencing individual participation in zakat contribution: exploratory investigation. Paper submitted for presentation 
at the Seminar for Islamic Banking and Finance 2006 (iBAF2006)

Mukhlis, A., \& Beik, I. S. (2018). Analisis Faktor-faktor yang Memengaruhi Tingkat Kepatuhan Membayar Zakat: Studi Kasus Kabupaten Bogor. AL-MUZARA'AH Journal of Islamic Economics and Finance, 1(1), 83-106.

Mustikasari Elia. 2007. Kajian Empriris Tentang Kepatuhan Wajib pajak Badan di Perusahaan Industri Pengolahan di Surabaya. Simposium Nasional Akuntansi X, Universitas Hasanudin Makassar.

Nisa, N. K. (2015). Strategi Kreatif Iklan Layanan Masyarakat (Ilm) Dalam Pemasaran Sosial. Interaksi: Jurnal Ilmu Komunikasi, 4(2), 158-164.

Nurudin. 2013. Pengantar Komunikasi Massa. Jakarta (ID): Rajawali Pr.

Pujiyanto. (2013). Iklan Layanan Masyarakat. Yogyakarta: Penerbit ANDI

Rahman, Fatkhur. (2010). Pintar Ibadah. Jakarta: Pustaka Media

Rosyadi, I. (2013). Model Prediksi Kepatuhan Menunaikan Zakat Maal. In Proceeding Seminar Nasional dan Call For Papers Sancall.

Sarwono, J. (2006). Metode Penelitian. Kuantitatif Kualitatif. Diambil dari eprints.stiperdharmawacana.ac.id

Setiawan, A. (2015). Strategi Kreatif Iklan Layanan Masyarakat (Tinjauan Perancangan ILM Karya Mahasiswa DKV UDINUS). Andharupa, 1(01), 17-32.

Sugiyono. (2015). Metode Penelitian Pendidikan: Pendekatan Kuantitatif, Kualitatif, dan RED. Bandung: Alfabeta

Syihabudin, Agus (2010) Pola Pembinaan Kesadaran Berzakat Dalam Meningkatkan Kepedulian Sosial: Studi Kasus di Rumah Zakat Indonesia. S3 thesis, Universitas Pendidikan Indonesia. 
Triyawan, A. (2017). Analisis faktor-faktor yang mepengaruhi muzakki membayar zakat di BAZNAS Yogyakarta. Islamic Economics Journal, 2(1).

Yusuf, Muhammad Asror. (2004). Kaya karena Allah. Jakarta: PT. Kawan Pustaka 